\title{
Peertechz
}

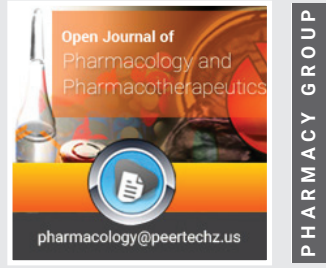

\section{An insight of mucormycosis (black fungus) in ayurveda}

\section{Mohsina FP' ${ }^{1 *}$, Faheem IP ${ }^{2}$, Tabassum $\mathrm{S}^{3}$, Shah $\mathrm{I}^{3}$ and Ahmad A ${ }^{3}$}

${ }^{1}$ Assistant Professor, Department of Pharmacology, Luqman College of Pharmacy, Gulbarga, Karnataka, India

${ }^{2}$ Assistant Professor, Department of Pharmacognosy, Luqman College of Pharmacy, Gulbarga, Karnataka, India

${ }^{3}$ Student, Luqman College of Pharmacy, Gulbarga, Karnataka India
Received: 23 August, 2021

Accepted: 01 September, 2021

Published: 02 September, 2021

*Corresponding author: Mohsina FP, Assistant Professor, Department of Pharmacology, Luqman College of Pharmacy, Gulbarga, Karnataka, India, Tel: +918904588538;

E-mail: mohsina.patwekar@gmail.com

Keywords: Mucormycosis; COVID-19; Ayurveda medicine; Anti-fungal; Ayush

https://www.peertechzpublications.com

Check for updates

\section{Abstract}

Mucormycosis, commonly known as black fungus, is a rare but serious fungal infection caused by a fungus called Mucormycete, which is abundant in the environment. It mainly affects people with preexisting diseases or people taking medications that reduce the body's ability to fight infections and disease. It is detected relatively frequently in COVID19 patients in several states of India. The disease usually manifests on the skin and also affects the lungs and brain. People who are suffering from COVID-19 and who are in recovery stage have a poor immunity and take the prevalence of disease higher and hence the immune system won't develop sufficient antibodies to fight against them. People hospitalized with severe COVID19 illness who were prescribed with steroids to reduce the infection. Steroids work by reducing inflammation in the lungs and reducing the body's immune response to preventtfrom attacking healthy cells in the body, resulting in a decreased ability to monitor immune responses. These patients are very sensitive to the effects of Mucormycete. This infection will not spread from personto person. This infection starts first in the nose and spreads to the eyes, then to the lungs and brain. This black fungus is now seen more frequently in post COVID19 Patients in India specifically. The present review is based over the ayurvedic treatment under AYUSH used for the black fungus infection.

\section{Introduction}

In India, second waves of COVID 19 suppressed. Meanwhile, the situation became more drastic, furious by the appearance of rare but previously known disease, named as MUCORMYCOSIS (black fungus).Both post -COVID \& non- COVID people are being hunted by this horrific fungal infection. Using Corticosteroid (main life rescuing treatment of severe, critical COVID patients) increases the mortality rate of 50 percent overall disease $[1,2]$.

\section{Causes}

A group of fungal molds, named as micromycetes or zygomycetes or Mucorales causes the terrific condition. These molds dwell inside soil, air, foods everywhere in the environment. They usually grows in thick patches near air conditioning, HVAC systems and ducting due to moisture from condensation old damp carpets can also grow spores of mucor. These enters directly inside body through eyes, nose, and mouth and expresses impact on the brain even. It can also occur on the skin after a cut, burn or another types of skin injury. The age doesn't matter here any person with low immunity including premature infants may be affected [3].

There are several risk factors of beings affected listed below:-

- Weak ventilation, defiled hospital accessories, contaminated wound dressings low pressured habitants

- Uncontrolled diabetic patients who have taken steroids or tocilizumals

- Patients with anticancer treatment

- Sufferers from a chronic debilitating illness

- Patients, depending on oxygen, who needs ventilatory support, nasal prongs

- High doses of steroids taking for longer days 
- Patients with kidney failures, liver cirrhosis, tuberculosis ,malnutrition ,organ transplant, HIV/ADIS, lymphoma, blood filled with iron

- Mostly patients who were under covid treatment within six weeks are highly susceptible of being infected

- Severe GVHD and its treatment. prolonged and profound neutropenia

- HSCT with high risk

- Prior VRCZ used [3, 4].

As per symptomatic area bases, the affected site division are:-

1) Rhinocerebral mucromycosis: - pain and swelling of face, headache, fever, black lesions on nasal bridge inside mouth.

2) Cutaneous mucromycosis: - swelling, ulceration, pain, warmth in skin, blackish discoloration of lesion.

3) Gastrointestinal mucromycosis :- vomiting with blood, abdominal pain , nausea bleeding in G I T

4) Pulmonary mucromycosis: - pain of chest, dyspnea, rising temperatures, cough, breathing problem.

5) Disseminated mucromycosis: - blood clotting due to spore invasion into the blood flow, death of tissue, changing mental status, and leading coma $[2,8]$.

6) Rare variants endocarditis, osteomyelitis, peritonitis, renal infection Rhinocerebral 39\%. Cutaneous $19 \%$. pulmonary 21\%. Disseminated 23\% Figure 1.

\section{Diagnosis of mucromycosis}

There are several method of diagnosis such as

- immuncomponents :-pulmonary involvement is not common if occur chronic symptoms upto 4 months
- Uncommon :-psuedoameurysms

- Asymptomatic mycetoma, solitary nodules.multiple mycotic pulmonary artery aneurysms.Radio graph of normal chest. Ulcerative tranchobronchitic in lung transplant [8].

\section{Culture}

Tissue swabs, or BAL cultures are usually non diagnostic. Here , direct using of microscope on bronchoalveolar lavage and transbronchial biopsy increase the yield. Rapid growth ( 3 to 7 days) sabouraud agar and potato dextrose agar incubated at $25^{\circ} \mathrm{C}$ to $30^{\circ} \mathrm{C}$. Aggressive vertical growth to word the lead of the Petri-dish - lid liftens specimens should be chopped rather them grounded CT and MRI show and spectrum findings Rhinocerebral mucromycosis imagine play a vital role in assessing the extent of involvement and complication.

Antigen detection and specific T-cells. Galactomannam and B - D Glucane if negative lively invasive mucormycosis than I P A Mucorales - specific T cells (E L I spot enzyme linked immune spots) assay [3].

\section{Aims \& objective}

- As per modern \& Ayurvedic science, understanding of Mucormycosis

- In prevention \& treatment of Mucormycosis, role of Ayurveda.

\section{Pathophysiology}

Infection of mucormycosis are marked by extensive angio-invasion. For that, subsequent tissue necrosis, vessel thrombosis takes place. Ischemic necrosis hinders delivery of leukocytes and antifungal agents to the foci of affected area.

\section{In case of orbital mucromycosis}

From outer environment, inhalation of fungal spores takes place, then spoors trapped in the paranasale sinus. Thus
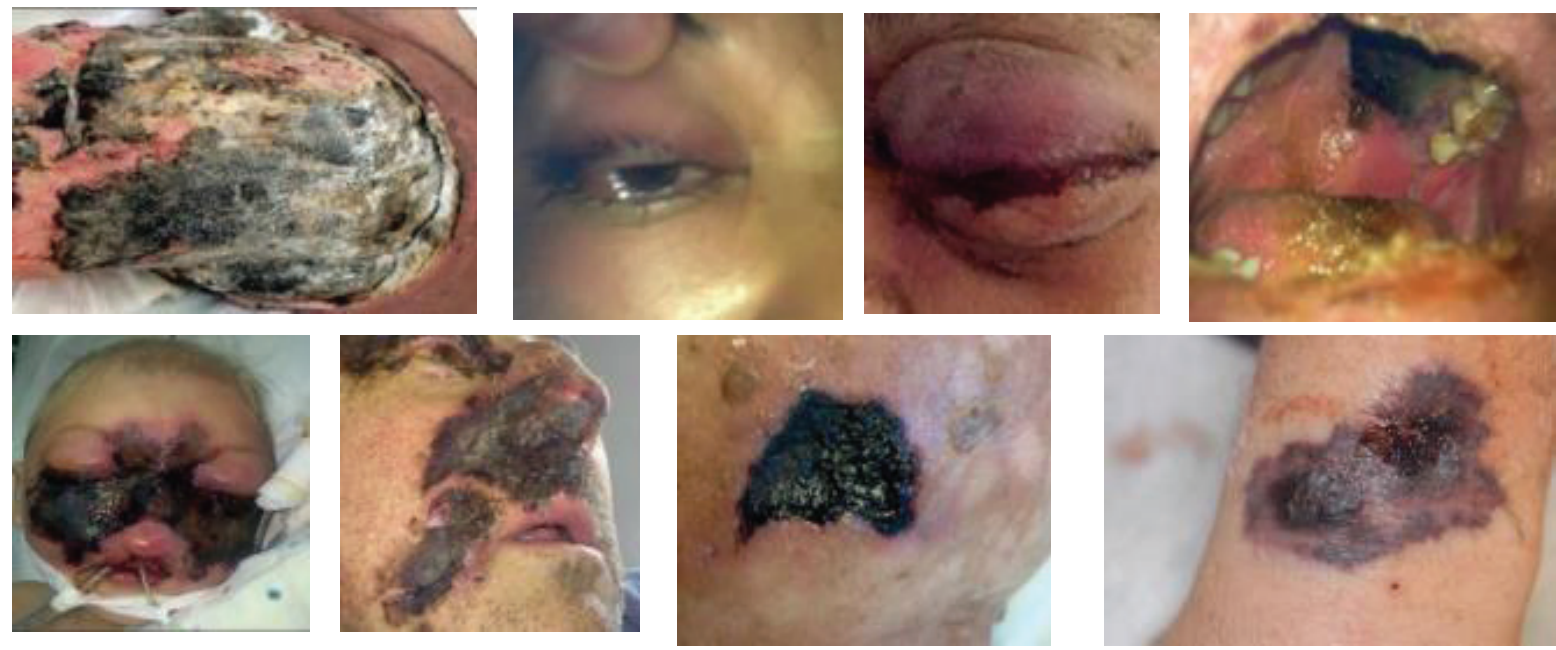

Citation: Mohsina FP, Faheem IP, Tabassum S, Shah I, Ahmad A (2021) An insight of mucormycosis (black fungus) in ayurveda. Open J Pharmacol Pharmacother 6(1): 013-017. DOI: https://dx.doi.org/10.17352/ojpp.000018 
colonization, blockage of macrophases take place, by which deficiency neutrophibo and hyperglycemia conduct. Fungal protifration with iron overloading followed by fungal invasion turns to word necrosis. Over necrosis is the reason of reducing immune response. Thus the spreading of infection throughout orbit appears [2].

\section{Rhinocerebral mucromycosis}

Causative agent is saprophytic fungi of class phycomycetes include mucor, rhizopus, absidia, cunnirghamella genera apophysomyces elegans. The humid environmental - of nose and paranasal sinuses choose the invasion, growing of fungi. early implementation of fungi is common in maxillary sinus with mass of fungal ball growth and no bone erosion inversion of blood vessels of fungal hyp hae damage the endothelium causing blood clots by which necrosis of tissue and is chemia turns on .specially for diabetic ketoacidosis patients, Hyperglycemia problematic for the immunity of body, phagocytosis of leukocytes neutrophils chemotosis, local inflammatory response is matter a lot for diabetic mellitus patients. Rhizopus \& thrives in ketone- reductase system glucose enriched medium iron chelator (dextrose amine) makes the iron available for fungal growth increase fungal virulence $[2,4,5]$.

\section{Pulmonary mucromycosis}

Innate immune response to mucromycosis is provided by mononuclear as well as polymorphoneuclear phagocytosis. Spore germinate into hyphal forms by overcoming mechanism. I .e the angioinvasive infection form. Various spores travel according to there size. Larger spores $(>10, \mathrm{um})$ lodges in nasal turbinates potentially causing isolated sinusitis. Most spores go towards distal alveolar spaces immuncomponents hosts can build up slowly progressing of pulmonary mucormycosis when exposed to inhalation of a high spore inoculum $[2,9]$.

\section{Allopathic treatment}

With the fast and aggressive treatment, mucormycosis can be eradicated. The concern is because of the fact that by the time even a presumptive diagnosis is made, the patient has often suffered significant tissue damage, which is not reversible. Most of them are under surgical treatment by Removal of black fungus affected area like palate, nasal cavity and eye structure. To treat each infected person 2oinjections needed. Antifungal medicines like amphotericin (through vein) and like posaconazole, isavuconazole (by mouth) are being used [3, 4].

\section{Ayurvedic treatment}

Experts from AYUSH departments have claimed AYURVEDA and UNANI formulations could help in preventing the spread of black fungus among the cured C-19 patients [6]. Shortage of medicine is vital problem. In medical emergencies, remedy to C-19 patients 'CASTOR OIL' can be used for eye care treatment as it has antifungal, antimicrobials properties.

Now a days, in absence of availability of suitable modern drugs, it can become a potential, cheap yet effective source as alternative medicine [6].

\section{nidana}

- Prameha /prameha

- Upadrava, ojoksayam, sthanam-kapha sthanam (ura, grahana, kanta sira)

- Laksanam(reference specific to Rhinocerebral Mucormycosis)

- Ama avastha-jvara, Nasarodha,

- Pacyamana-Avastha-jvara, mukha sopha, pratisyaya, raktapitta, sulam

- Pakvaavastha-Mukha-sopha, dhatupaka. Samprapti

rakta-vidagdha,

4 important factors for contribution to Samprapti Kleda vrddhi-as seen in prameha,

Ojoksayam-vyadhi aksamtavm, Dhatu daurbalyam-Vyadhi rupam, Pitta vidagdha-Sigrapaki

Laksana stages:

STAGE I -Kaphapradurbhava

STAGE II -Kaphavilayanam-pitta dusti

STAGE III -Pitta vidagdha-Vata pradurbhavam.

Dosas-kapha, pitta, vata; Dusya-Rasa, Rakta, Mamsa, Medas.

\section{Treatment Protocol}

- Kasaya Tikta Rasa Prayoga

- Rakta Prasadanam,Ojo Vrddhi

- Krmighna,initially

- Kapha pitta haram, Ruksa [6, 7].

STAGE I: Kasayam:

Aragvadadi kasayam

Amrtottaram kasayam

Guducyadi kasayam

Nimbadi Kasayam

Sonitamrtam kasayam

Katakakadiradi-kasayam(Toya-kalpana-for Diabetics)

Curnam-sudarsanam,Triphala-curnam,

Gulika-kaisora guggulu,siva gulika,krmighna ghana vati,visa vilvadi gulika

Lehyam(Manibhadra-gudam in minimal dosage)

Arsta(Vidhangarishtam) 
Rasa ousada (Arogyavardini vati, Mrganka rasa (Ref: Vaidya Chintamani) $[6,7]$.

\section{Visa vilvadi gulika (Kriya Kaumudi)}

\section{Ingredients}

Bilva, Tulasi, Karanja, Tagara, Devadaru, Marica, Daruharidra, Ajamutra, Haritaki, Vbhitaki, Amalaki, Sunti, Pippali, Haridra, Pathy a, Nilini, Isvari (50\%).

Visa vilvadi gulika - Darvikara visa cikitsa:

Kasaya Tikta Rasa, Visahara, Sophahara, Raktadosahara, Sulahara, Hrdya, Vranaropana [7].

\section{Dose}

Kasayam - 50ml - $50 \mathrm{ml}-50 \mathrm{ml}$ on empty stomach Gulika - 2-2-2 after food

Lehyam - 20gm at bed time

Arstam - $20 \mathrm{ml}$ with water thrice daily after food

Urdvajatru visesa kriya:

Nasya - Vasa svarasa, Dronapuspi svarasa Kavala Gandusa - Triphala kasya

Dhumapana-Murdha virecana-Aparajita (Sveta), Jyotismati, Haritalam, Manasila, Agaru [7].

*NOTE:

Haritala and Manasila should be used with care. In case of hypoxia, Dhumapana is contraindicated

\section{Stage II}

Madhusnuhi Rasayanam

Gandhaka Rasayanam

\section{Svarnamalini Vasanta Rasa}

\section{Mahatikataka Ghrtam}

Guggulu Tikataka Ghrtam. (Ghrtam should be given in later phase of recovery stage) [7].

\section{Kosatakyadi yavagu}

Ingredients: Kosataki, citraka, pata, Arka, Amrta, Abhaya, Selu, Sirisa, Kinihi, Haridra, Daruharidra, Punarnavadvayam, Trkatu, Brhati, Kantakari, Sariva Dvayam, Bala, Ksaudra.

\section{Pathya (Diet)}

Avoid urad dal, sesame seed/oil, dairy products, jaggery, sour foods, newly harvested rice, non vegeterian food [7].

\section{Aparajitha dhupam}

(Preventive \& precautionary)
Ingredients: Guggulu, Truna, Vaca, Sarja, Nimba, Arka, Agaru, Devadaru.

Phalasruti: jvaran sarvan vyapohati, Visesat visaman, Agantu \& Anubandhaja jvara [7].

*Note: Dhupam should be used carefully in a patient with respiratory distress

\section{Principles of ayurvedic treatment}

- Use of Laghu Ahora, Agni Dipaka drugs etc., plays an important role in prevention of post COVID complications like

- Mucormycosis. These are important for proper maintenance of homeostasis condition.

- Tankana Sphatika, yashada, shirisha, Panchavalkala etc., are used in eye drops preparation effectively

- As per Ayurvedic literature Rakataja krimi is compared with the pathogenesis of mucormycosis to prevent spread of this disease krimihara chikitsa is used.

- As liver is responsible for the production of immunoglobulins, the main defense mechanism components of the body. So, Yakritashodhaka and Raktaprasadaka drugs are also used in treatment.

- Kapha pitta nashaka and Vata Avirodhi Chikitsa plays a vital role in management of black fungus treatment.

- Shodhana by Shirovirechana with Vidanga Taila/ Shigru Taila and Vairechanika Dhooma is highly effective [7] Figure 2.

This chart tells about the number of cases of Mucormycosis in different parts of India. According to the chart, the state Gujarat and Maharashtra have their cases between 2000-2500. AndraPradesh, Madhya Pradesh and Rajasthan have cases between 500-1000. Other states like Telengana, Haryana, Delhi and Uttar Pradesh got cases between 0-500. Some other places like the Central Institutions where cases of Mucormycosis also take place at around 0-500 [12].

\section{Conclusion}

We know that fungal infection Mucromycosis is not new like covid-19. India's Mucromycosis prevalence to be 0.14 cases per 1000 population or at about 187460 patients in overall manner. When well treated from $30 \%$ to $46.7 \%$. The rate of mortality in Black Fungus is very high $80 \%$ with no treatment \& $40-50 \%$ with treatment. As per statistics, less than 50 people have been treated with ayurvedic medicines so far $[9,10]$. There are so many Ayurvedic treatments by which covid-19 as well as Mucormycosis will be eradicated. Instead of Allopathic Steroids, taking of medicine Ayush-64 will not be reason of Mucormycosis. Along with maintaining hygiene in hospital environment, mask worn, less moisture content in environment will help to make Mucormycosis, Covid-19 like pandemic free India $[11,12]$

Citation: Mohsina FP, Faheem IP, Tabassum S, Shah I, Ahmad A (2021) An insight of mucormycosis (black fungus) in ayurveda. Open J Pharmacol Pharmacother 6(1): 013-017. DOI: https://dx.doi.org/10.17352/ojpp.000018 


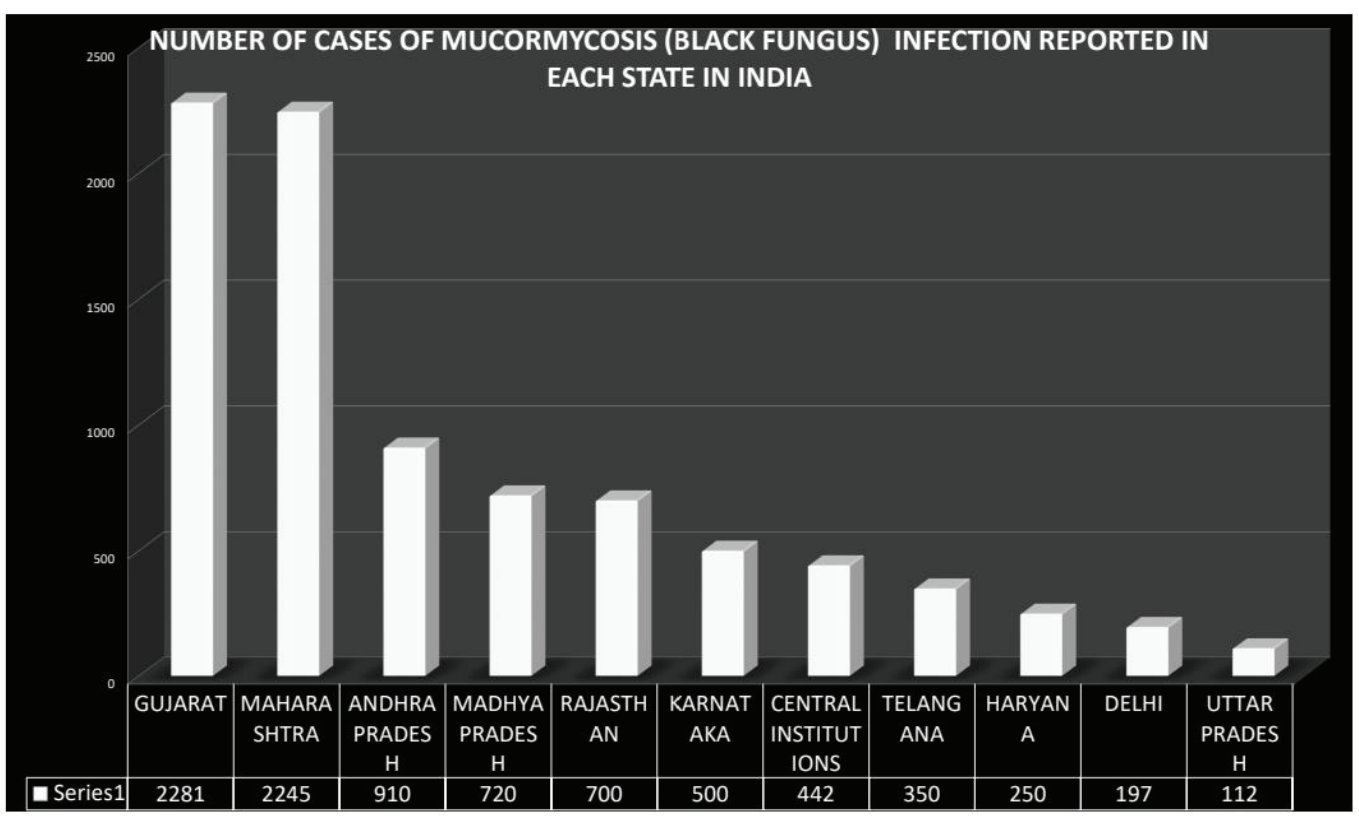

Figure 2: State wise Mucormycosis Statistics.

\section{References}

1. Kameshwaran S, Sriram N, Raju D, Manimekalai P, Dhanalakshmi M (2021) Symptoms and treatment strategy of black fungus in covi-19 patients. Int $\mathrm{J}$ Pharm Clin Res 5: 59-62. Link: https://bit.ly/2WFHoww

2. Petrikkos G, Skiada A, Lortholary O, Roilides E, Walsh TJ, et al. (2012) Epidemiology and Clinical Manifestations of Mucormycosis. Clinical Infectious Diseases 54: S23-S34. Link: https://bit.ly/3zv2kEK

3. Lewis RE, Kontoyiannis DP (2013) Epidemiology and treatment of mucormycosisexternal icon. Future Microbiol 8: 1163-1175. Link: https://bit.ly/3jynnRb

4. Hasegawa M (2017) Differential Diagnosis and Pathogenesis for Orbital Tumors. Japanese Journal of Neurosurgery June 26: 419-429. Link: https://bit.ly/3yD9J3A

5. Amphotericin B Vial. Link: https://wb.md/38tRNxF

6. Ministry of AYUSH Govt. of India, Guidelines for Ayurveda practitioner's for covid-19 Link: https://bit.ly/3DunVzH

7. Iyer's YM Sri Sarada Ayurveda Hospital Derisanamcope, Azhagiapandiapuram Post Kanyakumari Dist- 629851, Tamil nadu. \& Professor Dept of Kayachikitsa \& PG StudiesPankajakasthuri Ayurveda Medical College, Killy, Kattakkada.

8. PG Department of Panchakarma, Ayurveda Mahavidyalaya, Hubli, India.2, 3,4PG Scholar, PG Department of Panchakarma,Ayurveda Mahavidyalaya, Hubli, India. Corresponding Email id: mmrodd9655@gmail.com Access this article online: www.jahm.co.in Published by Atreya Ayurveda Publications under the license CC-by-NC-SA.

9. Walsh TJ, Gamaletsou MN, McGinnis MR, Hayden RT, Kontoyiannis DP (2012) Early clinical and laboratory diagnosis of invasive pulmonary, extrapulmonary, and disseminated mucormycosis (zygomycosis)external icon. Clin Infect Dis 54: S55-S60. Link: https://bit.ly/3mQ2YZX
10. Koshy J (2021) Mucormycosis not uncommon in India: Studies. Hindu. Link: https://bit.ly/38s0eJN

11. Ayurvedic medicines for Black Fungus cases. Link: https://bit.ly/3BruPDS

12. Link: https://bit.ly/3mUxRMT

Discover a bigger Impact and Visibility of your article publication with

\section{Peertechz Publications}

\section{Highlights}

* Signatory publisher of ORCID

* Signatory Publisher of DORA (San Francisco Declaration on Research Assessment)

- Articles archived in worlds' renowned service providers such as Portico, CNKI, AGRIS, TDNet, Base (Bielefeld University Library), CrossRef, Scilit, J-Gate etc.

* Journals indexed in ICMJE, SHERPA/ROMEO, Google Scholar etc.

* OAI-PMH (Open Archives Initiative Protocol for Metadata Harvesting)

* Dedicated Editorial Board for every journal

* Accurate and rapid peer-review process

* Increased citations of published articles through promotions

* Reduced timeline for article publication

Submit your articles and experience a new surge in publication services (https://www.peertechz.com/submission). 